\title{
PERSEPSI MASYARAKAT \\ TERHADAP IKLAN ROKOK DI NEGERI PASSO, KECAMATAN BAGUALA, KOTA AMBON
}

\author{
Yani Talakua \\ Prodi Sosiologi, STKIP Biak, Papua \\ yanitalakua13@gmail.com
}

\begin{abstract}
Smoking is a bad habit that has been done since the time of the discovery of tobacco. Initially smoking only aims to warm the body but, over time the habit becomes changed goal is as a requirement that can not be abandoned or can be said to be addicted. Without tobacco as if there is no pleasure in itself. This continued until the time of the industrial revolution in England until the emergence of cigarette factories to spread throughout the world. The majority of smokers worldwide are $\pm 47 \%$ male population while $12 \%$ are female population with different age categories. Various reasons people smoke a variety, among these people there are several factors that influence a person to smoke for example, prestige factors to be called "champion", and there are also people who say smoking can trigger inspiration and keupayaan thinking, even there is an interesting pantun used as justification for the smoking habit that is "there is a rooster on the roof, not smoking not handsome" there is also a saying that "smoking dead do not smoke is also dead." Smoking is one problem that is difficult to solve.

Moreover, it has become a national problem, and even international. This becomes difficult, because it is related to many factors that trigger each other, so as if it has become a vicious circle. Cigarettes are cylinders of paper length between 70 to $120 \mathrm{~mm}$ (varies by country) with a diameter of about $10 \mathrm{~mm}$ containing tobacco leaves that have been chopped. As for several types of cigarettes in Indonesia, among others: Djarum Super, Gudang Garam Filter, Gudang Garam Merah, Dji Sam Soe, Sampoerna Mild, Sampoerna Mild Menthol, Marlboro, Surya, U Mild and others. In terms of cigarette health can cause negative effects for active smokers and passive smokers, because each suction causing nicotine and carbon monoxide are very dangerous for both especially for active smokers who can cause various chronic diseases, such as lung cancer, bladder cancer, cervical cancer, breast cancer, esophageal cancer, digestion, kidney cancer, oral cancer, atherosclerosis, impotence and heart attacks, to death.
\end{abstract}

Keywords: society, ads, cigarettes 


\section{Abstrak}

Merokokmerupakan kebiasaan buruk yang dilakukan sejak zaman ditemukannya tembakau. Pada awalnya merokok hanya bertujuan untuk menghangatkan tubuh namun, lama kelamaan kebiasaan itu menjadi berubah tujuanya yaitu sebagai kebutuhan yang tidak bisa ditinggalkan atau dapat dikatakan kecanduan. Tanpa ada tembakau seakan-akan takadakenikmatan tersendiri. Hal ini berlanjut hingga zaman revolusi industri di Inggris hingga bermunculan pabrik-pabrik rokok sampai menyebar ke seluruh dunia. Mayoritas perokok di seluruh dunia ini $\pm 47 \%$ adalah populasi pria sedangkan 12\% adalah populasi wanita dengan berbagai kategori umur. Berbagai alasan orang merokok beraneka ragam, di kalangan masyarakat ini ada beberapa faktor yang mempengaruhi seseorang untuk merokok misalnya, faktor gengsi agar disebut "jagoan", dan ada juga orang yang mengatakan merokok boleh mencetuskan inspirasi dan keupayaan berfikir, malahan ada pantun menarik yang digunakan sebagai pembenaran atas kebiasaan merokok yaitu "ada ayam jago di atas genteng, tidak merokok tidak ganteng" ada juga yang mengatakan kalau "merokok mati tidak merokok juga mati."

Merokok merupakan salah satu masalah yang sulit dipecahkan. Apalagi sudah menjadi masalah nasional, dan bahkan internasional. Hal ini menjadi sulit, karena berkaitan dengan banyak faktor yang saling memicu, sehingga seolah-olah sudah menjadi lingkaran setan. Rokok adalah silinder dari kertas berukuran panjang antara 70 hingga $120 \mathrm{~mm}$ (bervariasi tergantung negara) dengan diameter sekitar $10 \mathrm{~mm}$ yang berisi daun-daun tembakau yang telah dicacah. Adapun beberapa jenis-jenis rokok di Indonesia antara lain: Djarum Super, Gudang Garam Filter, Gudang Garam Merah, Dji Sam Soe, Sampoerna Mild, Sampoerna Mild Menthol, Marlboro, Surya, U Mild dan lain-lain. Dari segi kesehatan rokok dapat menimbulkan efek negatif bagi perokok aktif maupun perokok pasif, karena setiap hisapan menimbulkan nikotin dan karbonmonoksida yang sangat berbahaya bagi keduanya terutama bagi perokok aktif yang dapat menimbulkan berbagai penyakit kronis, seperti kanker paru-paru, kanker kandung kemih, kanker serviks, kanker payudara, kanker kerongkongan, pencernaan, kanker ginjal, kanker mulut, penyakit aterosklerosis, impotensi dan serangan jantung, hingga meninggal dunia.

Kata Kunci: masyarakat, iklan, rokok

\section{PENDAHULUAN}

Fenomena merokok di kalangan masyarakat bukan suatu pemandangan yang asing lagi. Kebiasaan merokok telah menjadi budaya di berbagai bangsa di belahan dunia, Indonesia salah satunya, Indonesia merupakan salah satu negara dengan jumlah perokok terbesar di dunia. Hal ini disebabkan karena pada usia dini antara 5-9 tahun orang sudah mulai merokok. Hal tersebut tidak dapat terus dibudayakan, kita harus menyadari akan bahaya rokok dan kerugian-kerugian lainnya akibat merokok.

Merokok merupakan kebiasaan buruk yang dilakukan sejak zaman ditemukannya tembakau. Pada awalnya merokok hanya bertujuan untuk menghangatkan tubuh. Namun, lama kelamaan kebiasaan itu menjadi berubah tujuannya yaitu sebagai kebutuhan yang tidak bisa ditinggalkan atau 
dapat dikatakan kecanduan. Tanpa ada tembakau seakan-akan tak ada kenikmatan tersendiri. Hal ini berlanjut hingga zaman revolusi industri di Inggris hingga bermunculan pabrik-pabrik rokok sampai menyebar ke seluruh dunia.

Mayoritas perokok di seluruh dunia ini $\pm 47 \%$ adalah populasi pria sedangkan $12 \%$ adalah populasi wanita dengan berbagai kategori umur. Berbagai alasan orang merokok beraneka ragam, di kalangan masyarakat ini ada beberapa faktor yang mempengaruhi seseorang untuk merokok misalnya, faktor gengsi agar disebut "jagoan", dan ada juga orang yang mengatakan merokok bisa mencetuskan inspirasi dan keupayaan berpikir. Malahan ada pantun menarik yang digunakan sebagai pembenaran atas kebiasaan merokok yaitu "Ada ayam jago di atas genteng, tidak merokok tidak ganteng." Ada juga yang mengatakan kalau "merokok mati tidak merokok juga mati." Merokok merupakan salah satu masalah yang sulit dipecahkan. Apalagi sudah menjadi masalah nasional, dan bahkan internasional. Hal ini menjadi sulit, karena berkaitan dengan banyak faktor yang saling memicu, sehingga seolah-olah sudah menjadi lingkaran setan.

Rokok adalah silinder dari kertas berukuran panjang antara 70 hingga $120 \mathrm{~mm}$ (bervariasi tergantung negara) dengan diameter sekitar $10 \mathrm{~mm}$ yang berisi daun-daun tembakau yang telah dicacah. Adapun beberapa jenis-jenis rokok di Indonesia antara lain: Djarum Super, Gudang Garam Filter, Gudang Garam Merah, Dji Sam Soe, Sampoerna Mild, Sampoerna Mild Menthol, Marlboro, Surya, U Mild dan lainlain. Dari segi kesehatan rokok dapat menimbulkan efek negatif bagi perokok aktif maupun perokok pasif, karena setiap hisapan menimbulkan nikotin dan karbonmonoksida yang sangat berbahaya bagi keduanya terutama bagi perokok aktif yang dapat menimbulkan berbagai penyakitkronis, seperti kanker paru-paru, kanker kandung kemih, kanker serviks, kanker payudara, kanker kerongkongan, pencernaan, kanker ginjal, kanker mulut, penyakit aterosklerosis, impotensi dan serangan jantung, hingga meninggal dunia. Segi pergaulan para perokok dapat dengan mudah menularkan, menawarkan ataupun mempengaruhi tentang merokok kepada manusia lain, tanpa susah payah.

Negeri Passo terletak di antara dua jazirah yaitu jazirah Leihitu dan jazirah Leitimur. Negeri Passo Kecamatan Baguala Kota Ambon merupakan salah satu desa yang dikenal ramai jika dibandingkan dengan beberapa desa-desa lain yang berada di pulau Ambon, dikatakan demikian karena di Negeri Passo sudah terdapat beberapa tempat-tempat perbelanjaan yang ramai dikunjungi oleh orang-orang dari berbagai wilayah, bahkan transportasi di Negeri Passo begitu lancar dan bahkan sering terjadi kemacetan lalu lintas. Dengan adanya pusat-pusat keramaian yang ada di Negeri Passo sehingga pihakpihak dari industri atau perusahanperusahan rokok sering mempromosikan berbagai jenis barang dengan membuat reklame atau papan iklan di pinggiranpinggiran jalan untuk menarik perhatian setiap orang yang melewati tempattempat tersebut. Salah satunya adalah iklan rokok yang di pampang di papan reklame di depan kantor polisi, bukan saja melalui reklame tersebut tetapi sudah terdapat gambar-gambar diberbagai bungkusan rokok, koran, dan televisi. 
Bagi sebagian orang merokok merupakan suatu bagian dari hiburan untuk menenangkan pikiran dan juga merupakan inspirasi bagi orang yang merokok, dan merokok juga adalah suatu bagian dari proses untuk mendekatkan diri dengan lingkungan baru atau dikenal dengan kata lain pergaulan. Seperti di Negeri Passo, RT/RW 012/003, kalau dilihat bukan saja orang tua yang merokok tetapi ada juga anak-anak umur 14-18 tahun sudah menjadi perokok dalam pergaulan mereka. Ini bukan merupakan suatu hal yang baru lagi. Merokok seakan telah menjadi suatu kebutuhan primer bagi seseorang dalam kehidupannya, hal ini dapat dilihat dari berbagai bentuk warning (peringatan) yang telah dikeluarkan untuk bisa memperingatkan konsumen rokok tentang bahaya yang sebenarnya dari rokok yang kemudian tidak diindahkan oleh banyak orang. Pertanyaan kritis yang kemudian sangat relevan dengan permasalahan ini adalah mengapa sampai seseorang (perokok) rela untuk mempertahankan kualitas kesehatannya dibandingkan untuk berhenti merokok? Seperti dalam penjelasan Herbert Marcuse tentang hasrat adalah sesuatu keinginan tertentu yang dapat di ulang-ulang.

Dengan adanya iklan dan gambargambar tersebut tidak membuat orang yang mengonsumsi rokok merasa takut akan hal-hal tersebut bahkan mereka semakin meningkatkan minat merokok mereka. Dengan adanya masalah tersebut penulis memilih lokasi penelitian di Negeri Passo RT/RW 012/003, Kecamatan Baguala Kota Ambon. Jumlah penduduk yang berada di RT/RW 012/003 sebanyak 366 jiwa dengan jumlah perempuan 159 orang dan jumlah laki-laki 207 orang dengan jumlah kepala keluarga sebanyak 87. Dari kerangka berpikir di atas maka menjadi suatu hal yang menarik perhatian penulis untuk mengkaji lebih jauh dan mendalam lagi permasalahan ini dengan judul: Persepsi Masyarakat Terhadap Iklan Rokok di Negeri Passo RT/RW 012/003 Kecamatan Baguala Kota Ambon.

\section{KERANGKA TEORI}

Dengan mengikuti Mead, teoretisi interaksionisme simbolik cenderung menyetujui pentingnya sebab musabab interaksi sosial. Dengan demikian, makna bukan berasal dari proses mental yang menyendiri, tetapi berasal dari interaksi. Pemusatan perhatian ini berasal dari pragmatisme Mead, ia memusatkan perhatian pada tindakan dan interaksi manusia bukan pada proses mental yang terisolasi. Perhatian utama bukan tertuju pada bagaimana cara mental manusia mendapatkan arti dan simbol, tetapi bagaimana cara mereka mempelajarinya selama interaksi pada umumnya dan selama proses sosialisasi pada khususnya.

Manusia mempelajari simbol dan makna dalam interaksi sosial. Manusia menanggapi tanda-tanda tanpa berpikir. Sebaliknya, mereka menanggapi simbol dengan cara berpikir. Simbol adalah objek sosial yang dipakai untuk mereprensentasikan atau menggantikan apapun yang disetujui orang yang akan mereka representasikan (Charon, 1998: 47). Tak semua objek sosial dapat mempresentasikan sesuatu yanglain tetapi objek sosial yang dapat menggantikan yang lain adalah simbol, kata-kata, bendabenda fisik (artefak) dan tindakan fisik (contoh, kata kapal, palang salib atau kepalan tinju) semuanya dapat menjadi simbol. Orang sering menggunakan simbol untuk mengkomunikasikan sesuatu mengenai ciri mereka sendiri: misalnya, mengendarai Rolls-Royce untuk 
mengomunikasikan gaya hidup tertentu. Simbol adalah aspek penting yang memungkinkan orang bertindak menurut cara-cara yang khas dilakukan manusia. Karena simbol manusia tidak memberikan respons secara pasif terhadap realitas yang memaksakan dirinya sendiri, tetapi secara aktif menciptakan dan mencipta ulang dunia tempat mereka berperan (Charon, 1998: 69). Simbol dan arti memberikan ciri-ciri khusus pada tindakan sosial manusia dan pada interaksi sosial manusia. Tindakan sosial adalah tindakan dimana individu bertindak dengan orang lain dalam pikiran. Meskipun mereka sering terlibat dalam perilaku tanpa pikir, perilaku berdasarkan kebiasaan, namun manusia mempunyai kapasitas untuk terlibat dalam tindakan sosial.

Sesuai dengan pemikiran-pemikiran Mead, definisi singkat dari tiga ide dasar dari interaksi simbolik adalah:

a. Mind (pikiran): kemampuan untuk menggunakansimbolyangmempunyai makna sosial yang sama, dimana tiap individu harus mengembangkan pikiran mereka melalui interaksi dengan individu lain.

b. Self (diri pribadi): kemampuan untuk merefleksikan diri tiap individu dari penilaian sudut pandang atau pendapat orang lain, dan teori interaksionisme simbolis adalah salah satu cabang dalam teori sosiologi yang mengemukakan tentang diri sendiri (the-self) dan dunia luarnya.

c. Society (masyarakat): hubungan sosial yang diciptakan, dibangun, dan dikonstruksikan oleh tiap individu di tengah masyarakat, dan tiap individu tersebut terlibat dalam perilaku yang mereka pilih secara aktif dan sukarela, yang pada akhirnya mengantarkan manusia dalam proses pengambilan peran di tengah masyarakatnya.

Herbert Marcuse (1968), menyatakan bahwa iklan akan mendorong tumbuhnya kebutuhan palsu, menyebabkan orang berkeinginan untuk menjadi orang tertentu, misalnya dalam cara berpakaian, selera bermusik, termasuk pemilihan bacaan atau barang apapun yang disukai konsumen. Perkembangan atau perubahan kebudayaan pada masa itu, yakni masyarakat industri modern, menjadi salah satu hal yang banyak dikritik oleh Herbert Marcuse dalam karyanya One-Dimensional Man (1968). Masyarakat yang pada masa itu telah dicekoki oleh kemajuan teknologi seolah-olah melupakan apa yang sebenarnya penting bagi mereka, yakni sifat-sifat kemanusiaan dan luhurnya akal budi. Bahkan mereka seolah-olah menjadikan teknologi sebagai suatu hal yang sakral dalam pikiran mereka sendiri. Hanya manusialah yang bisa menentukan kemanakah arah perkembangan kebudayaan yang akan mereka ikuti, ke arah yang semakin maju atau semakin mundur. Dari pernyataan tersebut, maka bisa kita ambil sebuah gambaran bahwa masyarakat industri modern adalah masyarakat yang memang dibentuk untuk senantiasa berada dalam sebuah kebutuhan palsu yang bekerja sebagai bentuk dari kontrol sosial.

Secara ekonomi, masyarakat industri modern memang mengalami berbagai kelimpahan mulai dari kenyamanan dan keteraturan. Kemajuan pesat dalam bidang teknologi menjadikan manusia seolah terbebas dari cucuran keringat dalam pekerjaannya sehari-hari. Namun, menurut 
Marcuse semua hal itu hanya merupakan kenampakan dari luar saja dan halusinasi karena belum menyentuh pada hakikat manusia seutuhnya. Segala sesuatu harus dilihatdalamrangkakeseluruhankehidupan masyarakat dalam mengembangkan nilai-nilai kemanusiaannya secara utuh. Lebih lanjut, kemajuan di bidang material memerlukan tinjauan lebih mendalam, mengenai perkembangan pada bidangbidang lain seperti halnya moral dan kebudayaan, ataukah sebaliknya justru membawa korban.

Kemajuan teknologi secara pesat menurut Marcuse merupakan sebuah era perbudakan baru dimana teknologi dan masyarakatindustrimerupakan ungkapan kepentingan pribadi yang dipaksakan kepada massa. Masyarakat industri modern masih merupakan masyarakat yang teralienasi karena mengasingkan manusia-manusia yang menjadi warganya dari kemanusiaannya. Bahkan mereka tak menyadari bahwa sebenarya diri mereka juga ikut teralienasi. Struktur pasar yang ada saat ini, merupakan alat pemerasan dan penguasaan, karena motif mengejar keuntungan akan mendorong produsen menguasai konsumen, baik dengan memeras buruh (yang tidak lagi secara fisik) maupun dengan memanipulir kebutuhan (kebutuhan palsu).

Kebutuhanpalsuiniadalahkebutuhan yang dibebankan kepada individu oleh adanya kepentingan sosial khusus dalam represinya. Dengan demikian, kapitalisme telah menghasilkan suatu sistem 'perbudakan sukarela'. Iklan cenderung menggeser nilai guna menjadi nilai simbolis. Apapun produk yang diiklankan dan apa kegunaan atau manfaat produk itu, dalam iklan sering menjadi persoalan nomor kedua, karena yang lebih ditonjolkan pada akhirnya adalah nilai simbolisnya, yaitu bagaimana konsumen ketika menghadapi persoalan atau situasi yang kurang lebih sama seperti yang ditampilkan dalam iklan, maka tanpa berpikir panjang ia langsung ingat apa yang dijanjikan dalam iklan dan langsung mengonsumsi produk industri budaya yang ada dalam iklan tersebut. Di era masyarakat post-modern, iklan memang bukan sekedar media untuk mempromosikan sebuah produk, tetapi iklan boleh dikatakan telah menjadi sebuah sistem ide yang mampu mempengaruhi dan mengkonstruksi citra rasa atau selera masyarakat.

Pada dasarnya iklan cenderung terusmenerus berusaha memanipulasi cita rasa konsumen, dengan cara melebih-lebihkan, mendramatisasi, mensimplifikasi persoalan dan menjanjikan seolaholah semua persoalan dan kebutuhan konsumen akan teratasi hanya dengan cara membeli produk yang diinginkan. Iklan cenderung menggeser nilai guna menjadi nilai simbolik. Iklan pada dasarnya adalah agen sosialisasi dan imitasi. Bahkan iklan juga pada dasarnya adalah agen utama sekaligus instrumen yang paling efektif untuk memasyarakatkan ideologi pasar. Dalam kajian sosiologi ekonomi, secara garis besar ada dua pandangan dari para ahli tentang iklan.

Pertama, pandangan yang melihat iklan sebagai sarana pembujuk orang untuk membeli dan mengonsumsi barang yang sebetulnya tidak mereka butuhkan. Tokoh-tokoh dari Mazhab Frankfurt, seperti Adorno dan Marcuse, misalnya berpendapat bahwa iklan berpengaruh dalam memelihara masyarakat kapitalis dengan menciptakan kebutuhan palsu terhadap orang-orang yang dirayu dengan aliran barang-barang. Kedua, pandangan yang melihat iklan adalah 
bentuk komunikasi yang membantu menciptakan budaya kemasyarakatan tertentu. Di era globalisasi dan perkembangan informasi yang makin masif, berbagai kajian memang telah membuktikan bahwa yang berperan besar membentuk gaya hidup: budaya citra (image culture) dan budaya citra rasa (taste culture) sesungguhnya adalah gempuran iklan yang menawarkan gaya visual yang acap kali mampu mempesona dan memabukkan. Dalam iklan, tanda-tanda digunakan secara aktif dan dinamis, sehingga orang tidak lagi membeli produk untuk pemenuhan kebutuhan (need), melainkan membeli makna-makna simbolis (symbolic meaning), yang menempatkan konsumer di dalam struktur komunikasi dan dikonstruksi secara sosial oleh sistem produksi/konsumsi. Iklan telah menjadi seluruh hasrat (channel of desire) manusia dan sekaligus saluran wacana (channel of discourse) melalui konsumsi dan gaya hidup. Melalui iklan, masyarakat dikonstruksi untuk dapat membaca pesan-pesan komersial secara keliru, karena selain terjadi hiperbola, dalam iklan juga dikembangkan bentuk hegemoni budaya konsumen yang menwarkan impian-impian palsu. Kemauan merupakan salah satu fungsi hidup kejiwaan manusia, dapat diartikan sebagai aktifitas psikis yang mengandung usaha aktif dan berhubungan dengan pelaksanaan suatu tujuan. Tujuannya adalah titik akhir dari gerakan yang menuju pada sesuatu arah. Hasrat, adalah sesuatu keinginan tertentu yang dapat diulang-ulang. Kemauan, adalah kekuatan yang sadar dan hidup dan atau menciptakan sesuatu berdasarkan perasaan atau pikiran.
Dari beberapa pengertian di atas terdapat beberapa ciri-ciri hasrat diantaranya:

1. Hasrat merupakan "motor" penggerak perbuatan dan kelakuan manusia.

2. Hasrat berhubungan erat dengan tujuan tertentu, baik positif maupun negatif. Positif berarti mencapai sesuatu barang yang dianggap berharga atau berguna baginya. Sedangkan negatif berarti menghindari sesuatu yang di anggap tidak mempunyai guna atau harga baginya.

3. Hasrat selamanya tidak terpisah dari gejala mengenal ( kongnisi) dan perasaan (emosi). Dengan kata lain: hasrat tidak dapat dipisah-piasahkan dengan pekerjaan jiwa yang lain.

4. Hasrat diarahkan kepada penyelenggaraan suatu tujuan, maka dalam hasrat terdapat bibit-bibit penjelmaan kegiatan.

\section{METODE PENELITIAN}

Metode yang digunakan dalam penelitian ini menggunakan pendekatan penelitian kualitatif. Menurut Gorman dan Clayton, penulis kualitatif melaporkan meaning of event dari apa yang diamati penulis. Penulis terlibat secara partisipatif di dalam observasinya. Ia berada dan hadir di dalam kejadian tersebut. Ini yang disebut amatan langsung di sini. Maka itu, sifat kejadiannya juga bersifat spesifik (specific situations). Kejadian yang memiliki nilai spesial, mempunyai kekhususan tertentu. Gorman dan Clayton menjelaskan bahwa tujuan akhir dari metode penelitian kualitatif adalah memahami apa yang dipelajari dari perspektif kejadian itu sendiri, dari sudut pandang kejadiannya itu sendiri. Tidak 
dapat dipungkiri bahwa penulis akan ikut mempengaruhi realitas yang tengah ditelitinya - dan bisa juga mendistorsi peristiwa yang diamatinya. Akan tetapi, distorsi itu setidaknya diminimalisir oleh metode amatan yang dipakainya. Keadaan tersebutmenjadikan penulisilmiahkualitatif menerangkan pemaknaan kejadian/ peristiwa yang ditelitinya, menjadi seorang pencatat detil-detil berdasarkan perspektif dan sudut pandang kejadian/ peristiwa itu sendiri. Ia melaporkan pemahaman sebuah kejadian melalui kejadiannya sendiri (dalam Septiawan Santana K, 2007: 28-29). Lokasi penelitian yang dipilih adalah Negeri Passo RT/RW 012/003, Kecamatan Baguala Kota Ambon. Lokasi ini dipilih sebagai lokasi penelitian dengan melihat bahwa di desa ini masih terdapat masyarakat yang mengkonsumsi rokok meskipun sudah mengetahui dan melihat bahaya rokok melalui iklan. Dalam penelitian ini, data dikumpulkan dengan menggunakan teknik wawancara mendalam selama berlangsungnya penelitian yang dilakukan, dengan menyampaikan pertanyaan terhadap informan, berdasarkan pedoman wawancara yang disusun sebelumnya. Observasi atau pengamatan secara langsung terhadap objek penelitian selama berlangsungnya penelitian di lapangan. Observasi yang dimaksud adalah observasi partisipasi pasif. Sanifia Faisal (Sugiono, 2007: 66) menyatakan bahwa di dalam partisipasi pasif peneliti datang di tempat kegiatan orang yang diamati, tetapi tidak ikut terlibat dalam kegiatan tersebut. Adapula pandangan lain yang dikemukakan oleh Suparlan (Pattilima, 2007: 63) dalam pengamatannya, peneliti tidak terlibat dalam kegiatan-kegiatan yang dilakukan oleh pelaku yang diamatinya dan tidak melakukan suatu bentuk interaksi sosial dengan pelaku atau para pelaku yang diamati. Keterlibatan peneliti dengan para pelaku adalah dalam bentuk keberadaannya dalam arena kegiatan yang diwujudkan oleh tindakan-tindakan pelakunya.

Dokumentasi ini berupa foto-foto, dan rekaman yang akan dikumpulkan oleh peneliti untuk menyajikan fakta-fakta dilapangan. Analisis data kualitatif yang digunakan peneliti menggunakan analisis data kualitatif yang diusulkan oleh Seiddel (dalam Moleong, 2004: 249), yang prosesnya berjalan sebagai berikut: mencatat yang menghasilkan catatan lapangan, dengan hal itu diberi kode agar sumber datanya tetap dapat ditelusuri; mengumpulkan, memilah-milah, mengklasifikasikan, mensintesiskan, membuat ikhtisar, dan membuat indeksnya. Berpikir, dengan jalan membuatagarkategoridataitu mempunyai makna, mencari dan menentukan pola dan hubungan-hubungan, dan membuat temuan-temuan umum.

\section{HASIL DAN PEMBAHASAN Pemahaman atau Pendapat Masyarakat terhadap Iklan Rokok}

Teknologi secara fungsional telah menguasai masyarakat, bahkan pada fungsi yang substansial, seperti mengatur beberapa sistem norma dimasyarakat, misalnya sistem lalulintas di jalan raya, sistem komunikasi, seni pertunjukan, dan sebagainya. Begitu pula iklan adegan petualangan yang menakjubkan dalam iklan rokok seperti iklan rokok jarum super, ataupun adegan dalam iklan rokok bentol merah. Iklan-iklan itu begitu mengagumkan karena selain realistis, adegan-adegan tersebut mampu membawah setiap orang kepada kesan dunia lain yang maha dahsyat.

Dari iklan-iklan tersebut terdapat dua sisi yaitu sisi positif dan sisi negatifnya, sisi positif dari iklan tersebut adalah iklan 
yang dibuat perusahaan-perusahaan tersebut merupakan pemasukan bagi mereka yang membuat iklan tersebut dan setiap pemasangan iklan pada papan-papan reklame juga merupakan pemasukan bagi pemilik papan reklame yang disewakan dan juga pemasukan bagi daerah salah satunya pajak, dan sisi negatifnyaadalahiklanyang dibuatbukan saja gambar-gambar yang menakutkan tetapi juga ada berbagai gambar dengan adegan-adegan yang mengoda atau yang menantang seseorang untuk lebih baik, dari hal tersebut secara langsung sudah mengajak orang untuk mencoba berbagai gaya hidup tersebut. Kata Mead, ketika isyarat itu membawah arti khusus yang muncul terhadap individu lain yang memiliki ide yang sama, maka kita memiliki simbol-simbol yang signifikan. Hal inilah yang sering kita maksud dengan bahasa atau komunikasi melalui simbol-simbol. Mead mengatakan bahwa esensi pemikiran merupakan perbincangan pengalaman isyarat makna yang terinternalisir dimana kita juga dapat melakukanya atas dasar eksternal, yakni pengaruh dari orang lain. Di dalam berkomunikasi manusia menggunakan kata-kata atau simbol-simbol suara yang mengandung arti bersama dan bersifat standar. Makna sebuah tanda indentik dengan bentuk fisiknya dan dapat ditangkap dengan panca indra, sedangkan simbol bisa abstrak.

Menurut Karp dan Yoels (NarwokoBagong, 2004: 17). Nilai atau suatu makna sebuah simbol tergantung kepada kesepakatan orang-orang atau kelompok yang mempergunakan simbolitu. Menurut Leslie White (Narwoko-Bagong, 2004: 17-18) makna suatu simbol hanya dapat ditangkap melalui cara-cara nonsesoris, yakni melalui proses penafsiran. Makna dari suatu simbol tertentu dalam proses interaksi sosial tidak begitu saja bisa langsung diterima dan dimengerti oleh semua orang, melainkan harus terlebih dahulu ditafsirkan.

Iklan rokok yang dikeluarkan oleh pihak-pihak industri itu bagus agar setiap orang baik perokok maupun tidak merokok mereka sadar akan kesehatan mereka bukan saja kesehatan tetapi juga perekonomian mereka dan iklan rokok yang dikeluarkan memiliki sisi positifnya yaitu dapat membuat pemasukan atau keuntungan bagi pihakpihak yang mengeluarkanya dan juga sisi negatifnya yaitu iklan rokok yang dikeluarkan dengan berbagai jenisnya dapat membuat orang atau si perokok ingin mencoba akan hal baru dari rokokrokok yang diiklankan dengan berbagai gaya hidup setiap orang. jika ditinjau dari sisi kesehatan rokok memang sangat berbahaya bagi manusia akan tetapi jika ditinjau lebih mendalam lagi ternyata rokok membawa income yang besar bagi pendapatan negara, jika demi alasan kesehatan pabrik-pabrik rokok ditutup maka otomatis negara mengalami penurunan pendapatan dan hal ini tentunya akan berpengaruh pada pambanguanan nasional.

Menurutnya pula pandangan tiaptiap orang berbeda mengenai rokok, tergantung masing-masing orang menilai sendiri bagaimana dampak rokok bagi kesehatan mereka, sangat musthil jika seseorang yang sudah kecanduan rokok tiba-tiba berhenti merokok hal itu membutuhkan waktu yang panjang. Iklan rokok juga memiliki sisi positifnya bagi pihak industri dan pihak-pihak yang lain, karena itu merupakan pemasukan atau pendapatan juga bagi mereka yang mengeluarkan iklan tersebut. merokok 
mempunyai dua sisi yang berbeda, pertama sisi positifnya yaitu kenikmatan merokok dalam hal merokok dapat membuat seseorang merasa tenang dan dapat berpikir dengan baik bagi perokok. Kedua, sisi negatifnya merokok dapat membahayakan kesehatan mereka. Tapi jika iklan rokoknya seperti itu, ada baiknya perusahan rokok ditutup saja. dengan adanya iklan rokok tersebut tidak berpengaruh apa-apa terhadap kehidupan pribadinya dikarenakan itu hanyalah gambar semata saja. Akan tetapi saat ini ia mengkonsumsi rokok secara sembunyisembunyi dari orang tuanya.

Dari pendapat beberapa informan diatas dengan adanya iklan rokok yang dikeluarkan oleh pihak industri rokok sangat bagus, disebabkan dalam iklan tersebut terkandung ajakan dan informasi tentang bahaya merokok, serta mengingatkan konsumen bahwa ternyata bukan saja rokok membawa dampak yang buruk bagi konsumennya akan tetapi secara tidak langsung berdampak buruk juga bagi orang-orang disekitar perokok tadi, maksudnya asap rokok juga berbahaya bagi orang yang menghirupnya. Akan tetapi kesemuaannya itu tergantung pada para konsumen sendiri, apakah dengan melihat iklan rokok itu mereka lantas sadar dan mengerti tentang bahaya rokok ataukah sebaliknya? Tergantung masingmasing pribadi saja.

\section{Bahaya Merokok Bagi Kesehatan}

Meski semua orang tahu akan bahaya yang ditimbulkan akibat merokok, perilaku merokok tidak pernah surut dan tampaknya merupakan perilaku yang masih dapat ditolerir oleh masyarakat. Hal ini dapat dirasakan dalam kehidupan sehari-hari di lingkungan rumah, kantor, angkutan umum maupun di jalan-jalan. Dampak yang dihasilkan akibat kebiasaan merokok tidak hanya dirasakan oleh si perokok namun juga oleh orang yang ada disekitarnya.Untuk mengetahui bahaya merokok bagi kesehatan para perokok, sehingga untuk membuktikan kebenaranya penulismelakukan penelitian kemudian penulis telah melakukanya dengan mewawancarai enam orang tetapi jawaban mereka hampir seluruhnya sama sehinga penulis hanya mengambil empat dari keenam informan yang ada.

Merokok itu membuat kesehatan perokok menjadi terganggu karena rokok tersebut mengandung nikotin yang dapat menyebabkan berbagai penyakit seperti kanker, batuk, dan lain-lain seperti yang dihimbau oleh kesehatan jadi bagi para perokok untuk mengurangi nikotin yang ada dalam tubuh sering-sering mengkonsumsi minuman kopi dan makanan-makanan lain. Bahwa bahaya merokok bagikesehatanitu dapat membuat setiap orang baik perokok maupun bukan perokok mengalami masalah pada kesehatan mereka jadi bagi perokok aktif maupun perokok pasif lebih bagusnya mengurangi kebiasan merokok mereka, karena dengan merokok dapat merusak tubuh si perokok dan orang disekitarnya.

\section{Rokok sebagai Inspirasi Kerja}

Rokok telah menjadi benda kecil yang paling banyak digemari. Merokok telah menjadi gaya hidup bagi banyak orang, baik perempuan maupun lakilaki. Bagi setiap orang, waktu merokok boleh diangap waktu inkubasi dimana perokok mengunakan waktu ini untuk berfikir untuk menyelesaikan suatu masalah. Ada juga orang merokok untuk menghilangkan rasa capek ada pula orang mengatakan merokok boleh mencetuskan 
inspirasi dan meningkatkan keupayaan berpikir. Kebiasaanya merokok dilakukan setiap saat, baik pada saat kerja maupun santai, alasannya mengkonsumsi rokok yaitu rokok dapat membuka wawasan berpikirnya dan ia lebih merasa nyaman, akan tetapi kebiasaan merokoknya ini disesuaikan dengan pendapatannya, dan ketika ada orang yang melarangnya untuk berhenti merokok maka ia akan berkata bahwa ia tidak membeli rokok memakai uang mereka.

Merokok pada saat ada waktu untuk merokok tapi apabila dalam bekerja ia biasa merokok ketika ia merasa capek dan untuk membantunya berfikir, baginya rokok itu segala-galanya apalagi kalau tidak merokok satu hari saja ia merasa ada yang lain atau tidak nyaman. Dari pemaparan beberapa informan di atas maka dapat disimpulkan bahwa: merokok dapat membuat si perokok merasa lebih santai, merokok juga merupakan upaya menghilangkan rasa capek, dan untuk merefleksikan pikiran dari beban pekerjaan. Dengan semua pembahasan mengenai realitas masyarakat dalam menanggapi iklan rokok di Negeri Passo RT/RW 012/003, memberikan pernyataan bahwa dengan adanya iklan rokok tersebut merupakan suatu ajakan agar setiap orang menyadari akan kesehatan mereka bukan saja kesehatan tetapi pendapatan ekonomi mereka karena tidak semua orang ekonominya sama baik perokok maupun orang yang tidak merokok, tetapi itu semua tergantung dari masing-masing pribadi setiap orang.

\section{Pemahaman Masyarakat Negeri Passo RT/RW 012/003 terhadap Iklan Rokok}

Iklan merupakan suatu bentuk proses komunikasi yang dibuat sedemikian rupa tergantung dari barang apa saja yang akan diiklankan oleh pihak-pihak tertentu. Iklan secara tidak langsung mengajak setiap orang untuk mengikuti apa yang diiklankan. Begitu juga iklan rokok yang dibuat dan dikeluarkan oleh media masa, dilihat bahwa iklan rokok yang dikeluarkan tersebut lebih banyak menunjukan gaya hidup yang lebih baik sehingga orang lebih banyak menangapi sisi baiknya saja tetapi tidak tahu dampak negatif yang sebenarnya. Dari hasil penelitian ini menunjukan bahwa dengan adanya berbagai iklan rokok yang ada di dalam kehidupan masyarakat terlebih khusus di Negeri Passo RT/RW 012/003, itu merupakan suatu ajakan yang bagus atau yang baik bagi setiap orang baik dilihat dari sisi kesehatanya maupun sisi ekonominya tetapi tergantung dari masing-masing orang dalam menanggapinya.

Seperti yang dikatakan oleh Herbert Marcuse (1968), ia mengatakan bahwa iklan akan mendorong tumbuhnya kebutuhan palsu, menyebabkan orang berkeinginan untuk menjadi orang tertentu, misalnya dalam cara berpakaian, selera bermusik, termasuk pemilihan bacaan atau barang apapun yang disukai konsumen. Sama halnya dengan pendapat masyarakat Negeri Passo RW/ RW 012/003 dengan adanya iklan rokok tersebut maupun iklan-iklan lainya yang dibuat oleh pihak-pihak industri, iklan tersebut tidak mengganggu kehidupan setiap orang bahkan iklan tersebut mengajak orang untuk menjadi lebih baik tetapi orang melihat dan menanggapi iklan tersebut salah karena mereka hanya melihat sisi baiknya saja tetapi tidak tahu sisi negatif dari iklan tersebut.

Dengan berbagai kemajuan teknologi orang dapat menciptakan suatu kehidupan 
yang baru, seperti iklan rokok dengan berbagai bentuk gambar atau adeganadegan yang menantang tetapi apakah dalam kehidupan nyata hal tersebut terjadi seperti yang ada di dalam iklan? Realitas dan fakta yang penulis temukan di lapangan justru sangat relevan dengan konsep teoritis yang dijelaskan di atas. Berbagai bentuk iklan-iklan rokok yang bermuculan dimedia massa seakanmenjadi promotor dalam menunjukan seperti apa nikmatnya merokok yang tentunya juga turut berpengaruh terhadap peningkatan kebutuhan masyarakat terhadap rokok. Selain itu kecenderungan masyarakat di Negeri Passo RT/RW 012/003 merokok karena memang keterdesakan untuk memenuhi kebutuhan-kebutuhan tersebut. Fenomena yang kemudian muncul dan terlihat dari realitas tersebut adalah munculnya suatu proses aktualisasi diri terhadap berbagai bentuk kebutuhan yang sebenarnya cukup mendasar bagi mereka.

Ada beberapa hal menarik yang memang juga dapat penulis jelaskan bahwa sebenarnya fenomena merokok telah mengalami suatu proses transformasi yang paling mendasar dalam hal mempersepsikan kebutuhan merokok, yang dimana ditemukan bahwa rokok telah menjelma menjadi suatu kebutuhan primer bagi masyarakat di RT/RW 012/003. Setiap bentuk aktivitas kehidupan selalu dijalani dengan merokok. Tentunya dapat dilihat juga peran iklan yang cukup sentral dalam mensosialisasikan kegunaan rokok bagi masyarakat. Terlepas dari konsep teoritis Herbeth Marcuse di atas, ada beberapa hal yang juga turut berpengaruh terhadap kecenderungan seseorang untuk merokok salah satunya juga adalah sosialisasi lingkungan. Sangat sulit tentunya menemukan seorang perokok pasif yang tinggal dan hidup di lingkungan para perokok aktif. Hal ini sekaligus menjadi pintu masuk dalam menganalisis seperti apa fenomena merokok di lingkungan RT/ RW 012/003.

Proses sosialisasi melalui tindakan yang setiap hari dilakukan, tentunya menjadi satu ketertarikan tersendiri dan menjadi magnet dalam menarik minat seseorang untuk merokok. Pada masyarakat post-modern, iklan memang bukan sekedar media untuk mempromosikan sebuah produk, tetapi iklan boleh dikatakan telah menjadi sebuah sistem ide yang mampu mempengaruhi dan mengkonstruksi citra rasa atau selera masyarakat. Dalam hal ini sebenarnya juga dapat dilihat bahwa, intensitas peminat rokok juga turut dikonstruksi berdasarkan hadirnya iklan yang dengan sengaja menunjukan kenikmatan merokok kepada masyarakat. Hal ini sejalan dengan apa yang dikemukakan oleh Mead (2014) bahwa, simbol adalah aspek penting yang memungkinkan orang bertindak menurut cara-cara yang khas dilakukan manusia. Dikemukakan demikian karena, iklan tidak hanya mengandung makna simbolis biasa tetapi lebih dari pada itu, iklan mengandung satu makna realitas yang cukup kontekstual dengan kehidupan manusia oleh sebab itu iklan menjadi dasar yang cukup kuat dalam melegitimasi minat masyarakat terhadap rokok.

Teori ini menekankan kajian sosiologi pada interaksi antar individu dan pada proses dimana individu tersebut mengembangkan sudut pandang tentang mereka sendiri dan terhubung dengan sesama individu. Interaksionisme simbolik melihat hidup sebagai suatu proses sosial sehingga ada suatu sosialisasi di dalamnya. Fakta yang juga penulis temukan di lapangan bahwa ada kesadaran dari masyarakat tentang bahaya merokok, 
namun pertanyaan yang kemudian muncul adalah mengapa sampai masyarakat tetap saja mau untuk merokok? Pertanyaan ini sekaligus menjadi entry point dalam melihat seperti apa cara pandang masyarakat terhadap iklan bahaya merokok. Perlu disadari bahwa sesungguhnya berbagai bentuk warning merokok yang disebarkan melalui iklan-iklan hanya merupakan suatu proses sosialisasi dan edukasi terkait dengan pentingnya kesehatan dan bahaya merokok. Tetapi pada saat yang bersamaan juga perlu diketahui bahwa kecenderungan masyarakat untuk merokok bukan sematamata terkonstruksi melalui doktrin iklan dan sebagainya tetapi justru yang mendasari itu adalah aktualisasi keinginan yang bahkan telah menyamai posisi dari sebuah kebutuhan primer.

Mead (2014) menjelaskan bahwa manusia menanggapi tanda-tanda tanpa berpikir, sebaliknya mereka menanggapi simbol dengan cara berpikir. Ini berarti bahwa ada satu proses dimana manusia cenderung memaknai dan mendefenisikan arti dan makna yang sesungguhnya dari simbol-simbol tertentu. Pendefenisian tersebut akan berujung pada implementasi tindakan atas dasarmakna yang dimiliki dari simbol tersebut. Coleman (2014) menjelaskan bahwa, kecenderungan seseorang untuk bertindak selalu didasarkan atas pertimbangan dan pilihan yang sadar.

Dalam melihat fenomena iklan dan pengaruhnya terhadap masyarakat dapat dijelaskan bahwa, kecenderungan seseorang untuk merokok selalu didasarkan atas satu proses pertimbangan dan juga pilihan yang cukup objektif. Berbagai bentuk warning merokok yang mencoba mensosialisasikan tentang bahaya merokok, tidak memiliki pengaruh dalam merubah paradigma masyarakat.
Hal itu disebabkan karena keinginan untuk merokok bukan terkonstruksi melalui suatu makna simbolik, tetapi lebih dari pada itu termanifestasi dalam suatu bentuk ranah keinginan dan kebutuhan. Sehingga dapat dikatakan bahwa seseorang merokok bukan berdasarkan keinginan tetapi berdasarkan kebutuhan karena bagi seorang perokok aktif dalam satu hari dapat membeli 2-3 bungkus rokok untuk memenuhi kebutuhannya yaitu merokok.

\section{KESIMPULAN}

Berdasarkan uraian diatas mengenai Persepsi Masyarakat Terhadap Iklan Rokok di Negeri Passo RT/RW 012/003 Kecamatan Baguala Kota Ambon, bahwa iklan rokok yang dipajang di pinggiran jalan, di koran, di televisi, dan bahkan pada bungkusanbungkusan rokok merupakan suatu ajakan yang baik bagi setiap orang baik perokok maupun bukan perokok, maka dapat ditarik kesimpulan sebagai berikut:

1. Kebiasaan merokok. Orang merokok juga merupakan suatu kebiasan yang sering dilakukan oleh setiap orang (orang yang merokok) baik perokok aktif maupun perokok pasif sehingga dengan adanya iklan rokok tersersebut tidak membuat si perokok merasa terganggu dengan iklan rokok tersebut, karena orang sudah mengenal rokok sejak rokok pertama kali dikeluarkan dan sebelum adanya iklan rokok tersebut.

2. Adapun faktor-faktor yang mempengaruhi seseorang merokok atara lain faktor lingkungan, baik lingkungan masyarakat, lingkungan pendidikan maupun lingkungan keluarga karena seseorang merokok juga dapat dipengaruhi oleh orang lain terutama di dalam pergaulan 
karena secara langsung di dalam pergaulan orang ingin mencoba sesuatu yang baru dan belum pernah dirasakan oleh orang tersebut.

3. Dampak positif dan dampak negatif dari iklan rokok. Dari pembahasan pada bab-bab sebelumnya ada berbagai tangapan yang berbedabeda mengenai iklan rokok, ada yang mengatakan bahwa iklan rokok tersebut memiliki sisi positif dan juga ada yang mengatakan iklan tersebut memiliki sisi negatifnya. Dikatakan sisi positif karena iklan yang dikeluarkan oleh pihak pemerintah maupun pihakpihak industri, bahwa iklan yang dikeluarkan hanyalah ajakan positif dan tidak mengganggu kenyamanan masyarakat terutama bagi seorang perokok. Iklan yang dipasang atau yang dikeluarkan pihak industri tersebut itu juga merupakan pemasukan atau pendapatan bagi pihak-pihak tertentu atau bagi mereka yang mengeluarkan atau memproduksi ikan-iklan tersebut dan juga pemasukan bagi negara karena setiap pemasangan atau penjualan suatu barang dikenai pajak dan dari pajak tersebutlah yang menjadi pemasukan bagi negara, dan sisi negatifnya dari iklan rokok tersebut adalah iklan yang dipromosikan melalui media masa dengan berbagai macam bentuk bukan saja gambargambar yang menyeramkan tetapi iklan tersebut dibuat dengan berbagai gaya hidup yang lebih oke sehinga iklan rokok tersebut secara tidak langsung mengajak setiap orang untuk mencoba mengonsumsi rokok yang diiklankan dan mengikuti gaya hidup yang ada dalam iklan tersebut. Seperti yang kita lihat pada gambar atau iklan yang dipajang pada reklamereklame di pinggiran jalan atau televisi bahwa iklan tersebut lebih banyak menunjukkan atraksi-atraksi seseorang yang menantang sehingga membuat orang ingin mencoba gaya hidup yang diiklankan, tetapi tak selamanya iklan tersebut dapat dibuktikan dalam dunia nyata atau dalam kehidupan seharihari.

\section{DAFTAR PUSTAKA}

Ahmadhi, Abu. 2004. Psikologi Umum. Jakarta: PT Rineka Cipta.

Bungin Burhan M.H. 2006. Sosiologi Komunikasi. Jakarta: PT Kencana Prenada Media Group.

Budiardjo Miriam. 2010. Dasar-dasar Ilmu Politik Jakarta: PT Gramedia Pustaka.

K. Septiawan Santana. 2007. Menulis Ilmiah: Metode Penelitian Kualitatif, Jakarta: Yayasan Obor Indonesia.

Moleong, Lexy J. 2004. Metode Penelitian Kualitatif, Bandung: PT. Remaja Rosdakarya.

Narwoko Dwi. J dan Suyanto Bagong. 2004. Sosiologi (Teks Pengantar dan Terapan), Jakarta: PT Kencana.

Panuju, Redi. 1996. Ilmu Budaya Dasar dan Kebudayaan. Jakarta: PT. Gramedia.

Ritzer, George. 2004. Teori Sosiologi Modern (Edisi Ketujuh). Jakarta: Kencana Prenada Media Group.

Suyanto, Bagong, 2013. Sosiologi Ekonomi: Kapitalisme dan Konsumsi Di Era Masyarakat Post-Modernisme. Jakarta: Kencana Prenada Media Group.

Zeitlin M Irving. 1995. Memahami Kembali Sosiologi. Yogyakarta: Gadjah Mada University Press. 